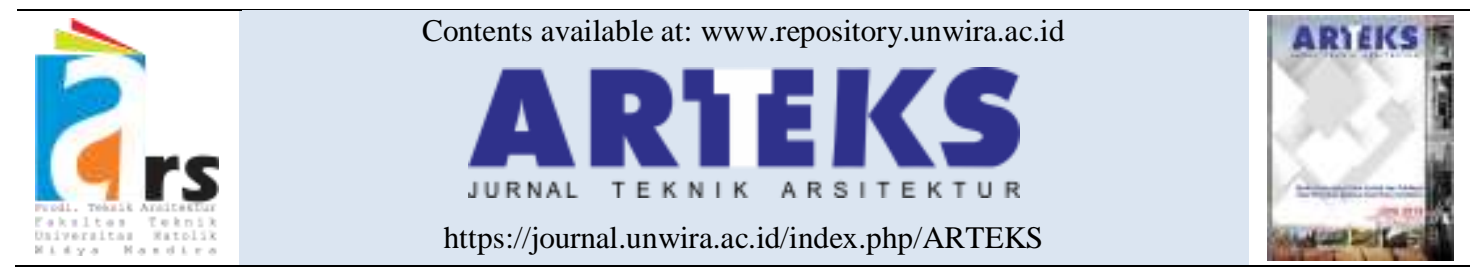

Research paper

doi: $10.30822 /$ arteks.v6i3.880

\title{
The challenge of city competitive advantage-rethinking creative city networking
}

\author{
Eko Nursanty ${ }^{1 *} \mathbb{0}$, Indah Susilowati ${ }^{2}$ \\ ${ }^{1}$ Department of Architecture, Faculty of Engineering, \\ Universitas 17 Agustus 1945 Semarang \\ Jl. Pawiyatan Luhur-Bendan, Semarang, Indonesia \\ ${ }^{2}$ Department of Magister Management, Faculty of Economics and Business, \\ Universitas Diponegoro \\ Jl. Sudharto no 1, Tembalang, Semarang, Indonesia
}

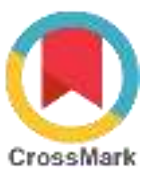

\begin{tabular}{|c|c|}
\hline ARTICLE INFO & ABSTRACT \\
\hline $\begin{array}{l}\text { Article history: } \\
\text { Received January 08, } 2021 \\
\text { Received in revised form Feb. 24, } 2021 \\
\text { Accepted July 06, } 2021 \\
\text { Available online December 01, } 2021 \\
\end{array}$ & $\begin{array}{l}\text { Competition between cities in globalization has been made through } \\
\text { various efforts. The city must also win a competition through brands } \\
\text { in the form of quality of life of creative cities. UNESCO also lists the } \\
\text { need for an optimal effort to develop the community's culture and } \\
\text { creativity to stimulate the city's regeneration into sustainability. The }\end{array}$ \\
\hline $\begin{array}{l}\text { *Corresponding author: Eko Nursanty } \\
\text { Department Architecture, Faculty of } \\
\text { Engineering, Univesitas } 17 \text { Agustus 1945, } \\
\text { Semarang, Indonesia } \\
\text { Email: santy@ untagsmg.ac.id } \\
\text { ORCID: https://orcid.org/0000-0001-7326- } \\
8153\end{array}$ & $\begin{array}{l}\text { study aims to dissect the city of Pekalongan as a case study. The } \\
\text { research uses qualitative methods with data collection through the } \\
\text { Big Data harvesting process analyzed through the interpretation } \\
\text { process. The findings are the relationship between the physical } \\
\text { elements of city space and the strong meaning concerning the } \\
\text { creative abilities possessed by its people, both tangible and } \\
\text { intangible. It is this strength that underlies the distinctive and } \\
\text { sustainable cultural development to build a city competitive } \\
\text { advantage. }\end{array}$ \\
\hline
\end{tabular}

\section{Introduction}

UNESCO Creative Cities Network (UCCN) is an institution that promotes various collaborative efforts among several cities that can identify their identities through their economic creativity. UCCN was founded in 2004 and had 246 members worldwide, and jointly strives to achieve sustainable development for their cities.

What is meant by sustainable development is an effort to work together to achieve a common goal, namely, placing creativity and the cultural heritage industry as the main priority in the active development of their cities both at the local and international levels.

A city is a place that gives us an idea of the ownership and identity of the owner. In this urban space, there has been a mixture of lifestyle and its inhabitants' creative potential. The resident community's life concerns the tastes and environment in which the place is located and becomes the potential for developing creativity and uniqueness according to the existing context (Bawole 2020).

One of the meanings of innovativeness is a cycle that can help people accomplish their ideal social dreams. Imagination is likewise fit for 
being another monetary motor, where the idea of an innovative city squeezes HR is the central part of the improvement of metropolitan strength. Consequently, the inventive city turns into a unique idea, zeroing in on inventiveness, local area improvement, and culture as the primary pointers to get a lively, agreeable, practical, and creating city for people in the future (Varbanova 2007).

An aspect that is quite important in developing a sustainable creative city is introducing history and memories of local culture, cultural resources, and art to society in the existing public space. Efforts to develop a place attachment that is unique and meaningful for people who live and work in the city will make the residents feel, "I love this city" that is an attraction for visitors and tourists who come (Florek 2011).

This paper will focus on the concept of a creative city both in theory and practice using a case study on the city of Pekalongan in Central Java, Indonesia.

The concept of a creative city that refers to creativity is always attached to art and culture that can create new industries and open job opportunities.

From the perspective of the urban economy, creative cities are expected to solve homelessness and inadequate urban environmental facilities, as revealed in several previous studies using the concept of creative cities as an effort to promote sustainable urban development (Sasaki 2010).

As part of the development of the city's potential, vibrant culture and long history, Indonesia has become part of the Creative City Network through 3 existing cities, namely: (1) Bandung since 2015; (2) Pekalongan since 2014 and (3) Ambon since 2019 as can be seen in figure 1 below.

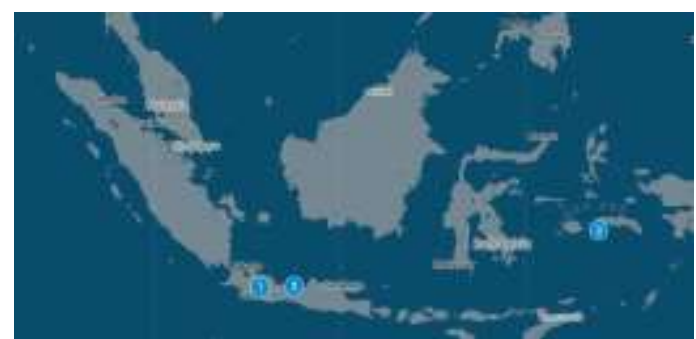

Figure 1. Distribution of UNESCO Creative City Networking in Indonesia

Creative City Network covers seven creative fields: Crafts and Folk Arts, Media Arts, Film, Design, Gastronomy, Literature, also Music. The three cities mentioned above are unique based on society's position and history, where Pekalongan is part of the Craft and Folks Art; Bandung is a city of design and Ambon as a city of music.

This research will focus on the city of Pekalongan is the first city to get a position as a member of the creative city network as a case study evaluating the role of $\mathrm{CCN}$ as part of increasing the city's competitive ability, considering that Bandung and Ambon are respectively provincial capitals and Pekalongan is a municipal city become part of the province of Central Java. Thus, the variable aspects and findings of this study can be used in other similar cities in Indonesia.

\section{Method}

The research was conducted using a qualitative interpretive method in cities that have obtained similarities as Creative City Network members in the UNESCO list of creative cities. Data collection was carried out using internet data from both the official UNESCO page and significant data harvesting on social media. The case study was conducted in Pekalongan city. Measurements are made using several qualitative variables on people and places that affect their ability to change space's strength. The method used is the "Butterfly Mamoli" method, where this concept tries to compare the community's idealism as the owner of the space in using the space (Nursanty 2021), as shown in the figure 2 below.

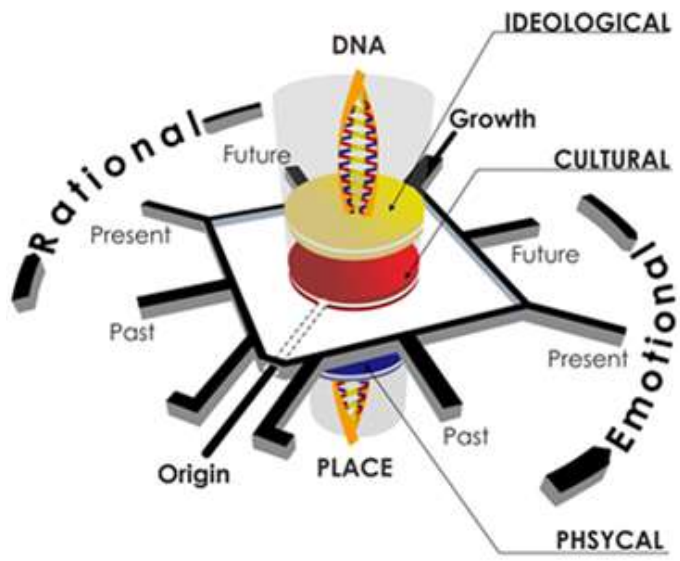

Figure 2. Butterfly mamoli concept

Big data is large volumes of information generated quickly, digitally coded, and often 
linked to other network data and can provide valuable evidence for studying phenomena. This research explores qualitative research's potential using an analysis process on big data, including text retrieval, interpretive analysis, visualization of information and data, etc. (Mills 2018). The Internet Big Data supports a qualitative research process, covering everything from its analytical potential to its methodological and ethical procedures. The data generated in everyday life is digitally mediated, stored, and analyzed in the present. Thus, big data is defined as digitally encoded information in a new scope and scale about a phenomenon interconnected and related to other network data (Mills 2018).

The case study selection was carried out in a structured manner in cities with the same potential, namely in the form of port cities in the past, and which have been registered in the UNESCO Creative City Network. It is done to find a similar phenomenon in human relations and place as an element forming branding in the world's creative cities (Oaks, Aberdeen, and Psychology 2013; Yin 2008). The analysis was carried out using a mixed-method, namely by combining Big Data harvesting with the rational systematization of the "Butterfly-Mamoli" analytical method. Big Data harvesting is done to overcome the obstacles that occur due to social distancing during the COVID-19 pandemic.

\section{Result and discussion}

Creative people and better place for life

The concept of a creative city was started in 1988, which introduced a new paradigm of sustainable urban planning. A creative city must include the elements of efficiency and equity for its citizens to get the opportunity to develop creativity in a maximum and satisfying way (Yencken 1988).

The concept of the creative city, both in principle and practice, alludes to the assembly of inventiveness characteristic in expressions and culture to make new ventures and open positions to cultivate the limit regarding urban monetary development. It is accepted to have the option to advance a far-reaching metropolitan recovery measure (Landry 2008). At first, creative cities were thought to emerge through cultural creativity and social inclusiveness. At that time, the Florida theory prevailed where there was a misperception that the city prospered when people from creative circles, such as artists, etc., gathered. Drawing in individuals from the innovative class does not make a city inventive (Costa 2007). A study conducted in Kanazawa City clarified that a creative city needs a balanced 'culture-based production system' in which a social creation framework and social utilization use the social gathering as its primary capital. A few different examinations in urban areas in Japan, like Osaka's city, likewise found that inventive city approaches neglected to deliver agreeable outcomes since they did not flourish as a far-reaching metropolitan technique (Sasaki 2010).

Several cultural centres in Europe initially carried out the idea of creative emergence as a new urban model. In this case, the inventiveness natural in expressions of the human experience and culture is utilized to make another industry and set out occupation open doors. The formation of new openings for nearby specialists and social onlookers can, at last, fortify the city to develop particularly and initially (Florida 2004).

Furthermore, several studies have proven that trying to attract someone who is considered to have creative potential from a creative group does not automatically make a city creative. These cities also need to develop creative industries that function as economic engines, and a large number of workers who have special skills are required to participate in it (Scott 2014).

Thus, if the city's economy does not have the marketing capabilities that allow it to thrive globally, sustainable development will remain challenging. On this side, it is beginning to understand the importance of culture and the information-based urban economic sector in the local economy and oriented towards exports as the mainstream replacing the import industry that was previously very popular (Blakely and Leigh 2013). Some cities that seek to pursue exportoriented economic development often undertake their efforts through mass production. They tend to have few consumers in place and minimal industrial fields.

On the other hand, import substitution can be carried out by focusing on the cultural industry to increase consumption in the region, producing a diverse and higher quality workforce, for example, human resources in developing new knowledge based on industrial information. It is crucial to analyze artists' roles in creative cities at various levels, such as social, cultural, and economic roles (Markusen 2006). We can call this 
new industrial development method for urban economic development through high-quality culture through a research model that has been carried out in the city of Kanazawa which is called the 'cultural mode of production utilizing cultural capital' which consists of 5 (five) elements as follows (Sasaki 2011; The Japan Foundation and Programme 2009). Delivering merchandise and ventures with high social added esteem, through the combination of specialists' abilities and affectability with cutting edge devices in the creation cycle; (ii) Making a design connected to the natural business that is intently interlaced between endogenous creating organizations in the area, from the social products industry to the innovative programming and plan industry, to (iii) Course income procured outside the district into the locale, with objectives towards new social speculations; (iv) Social speculation is utilized for the development of exhibition halls and backing from private plan research focuses, and so forth to expand the convergence of culture in the city to deliver advancement and foundation in the territories of cutting edge inventive local gatherings as HR for social creation; (v) Social utilization improves the nature of neighborhood buyer showcases and energizes social interest through buyers who can appreciate products and enterprises of high social quality and quality.

\section{Creative place for city creative}

The urban communities of the present reality have put all together in the social framework and creative economies. Culture is accepted as a method for metropolitan recovery, financial development, and social consideration (Comunian 2011). Creative city theory must face challenges and offer creative solutions to social discrimination problems such as people with disabilities, older people, homelessness, and all forms of discrimination as problems that must be resolved. The present inventive urban areas are viewed as very optimistic, endeavours made to support liberality and creative mind, which decidedly impacts traditional culture. The way of thinking is that there is, in every case, more imaginative, likely someplace. It expresses that conditions should be made for individuals to think, plan, and act with a creative mind to make the most of chances or manage metropolitan issues that appear to be hard to settle (Costa 2007).

The approach to investment efforts in the creative economy has developed new competition types between one city and another. The focus of economic strategy and policies has moved towards what cities should have to be "creative." Unfortunately, current policies are often replicated without considering the specific aspects of the place and the conditions. The cultural dynamics dramatically influence the current creative perspective and often consume tourists or visitors to a city. The innovative city strategy approach is firmly identified with the meaning of an inventive city identified with the general detailing of monetary arrangements and is related with the new repositioning of social enterprises and recovery in metropolitan turn of events. 'Imagination' is considered in the broadest sense by looking at how development can assist urban areas with tackling their day by day issues (Landry 2005). The concept of a creative city has various connotations related to alternate points of view on social utilization and creation. It is frequently a logical inconsistency between the "inventive city" as worldwide talk and its application in nearby metropolitan turn of events. The possibility that culture is a motor to help a city's picture and monetary advancement is additionally reflected in the collaboration among specialists and the local area.

\section{Craft and folks as culture}

Intangible cultural heritage in the form of culture is closely related to its traditional craft form. The craft can tell the story of a life that has been lived. Also, about the past and the way people live in it. Craft describes the evolution of existence, showing the role of ritual and tradition in producing it. Art incorporates devices, garments and adornments, outfits and props for celebrations and performing expressions, stockpiling compartments, objects utilized for capacity, transportation and haven, enlivening expressions and ceremonial articles, instruments and family utensils, and toys, both for diversion and instruction (Dormer 1997) as illustrated in figure 3 below.

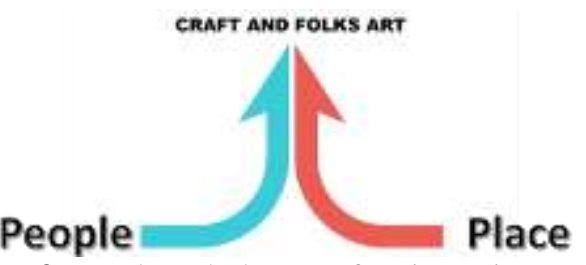

Figure 3. People and places as forming unique crafts and works of art 
Many of these craft items were initially meant only to be used for a short period, such as those made for festival ceremonies, while others were created to be heirlooms passed down from generation to generation. The abilities engaged with making handiwork objects assorted as the things and materials themselves are immaterial social legacy. The improvement of globalization presents critical difficulties for the coherence of conventional craft structures, regardless of whether at the degree of enormous worldwide organizations or neighbourhood bungalow ventures, large scale manufacturing can regularly supply merchandise required for day by day life at lower costs, both in cash and time, than carefully assembled creation (Campbell 2005). Many traditional artisans have difficulty adapting to this competition. Ecological and environment pressures likewise affect crafted by customary specialities, just as the diminished accessibility of critical regular assets, in situations where conventional craftsman form into house enterprises, expanding the creation scale can here and there bring about natural harm.

Some of the time, conventional art includes 'proprietary advantages' that are not instructed to untouchables. Be that as it may, if relatives or local area individuals are not keen on learning it, this information can be lost while offering it to outsider's disregards convention. Later on, this should be possible in a reasonable way through endeavours to create conventional artworks while simultaneously finding new business sectors and enabling craftsmen (Fuller, Hamilton, and Seale 2013). Historically, more specialized crafts with high-value products concentrated in city centres and formed trade unions. The skills required by their profession and the need to engage in commodity exchanges permanently often demand a generally higher education level. The craftsmen's production house usually does not stand independently but must depend on the exchange of goods (Huhtamaa 2010).

Handicraft is a significant sector of "traditional" crafting where it is a type of work in which useful tools and ornaments are made entirely by hand or using only simple tools. Usually, this term is applied to the traditional way of making goods. The expertise of the individual items is the most crucial criterion. These things regularly have social as well as strict importance. Things made by large scale manufacturing or by machines are not handiworks. Speciality things are made by the art creation measure (Ingold 2016).

Pekalongan city as a case

Several studies that have been carried out on craft production results, both implicitly and explicitly, have now generally been integrated into other broader forms of research, including through investigations of social and political structures (Costin 2001). It is further explained that there are 3 (three) ways to link the study of craft production and sociopolitical organization, namely: (1) the first way is the role of specialization of expertise in the hierarchical creation and maintenance of society; (2) the second way in which consideration of the social and political implications of the organization of production for social structures and social processes. This perspective provides information about the current specialization, regardless of the production aspect; (3) the third way is where the study of craft production is articulated with social studies. An investigation is carried out on the uses and social meanings of handicraft objects (Costin 2015).

Figure 4 below illustrates the process taking place in Pekalongan, designated as the World Creative City since 2014.

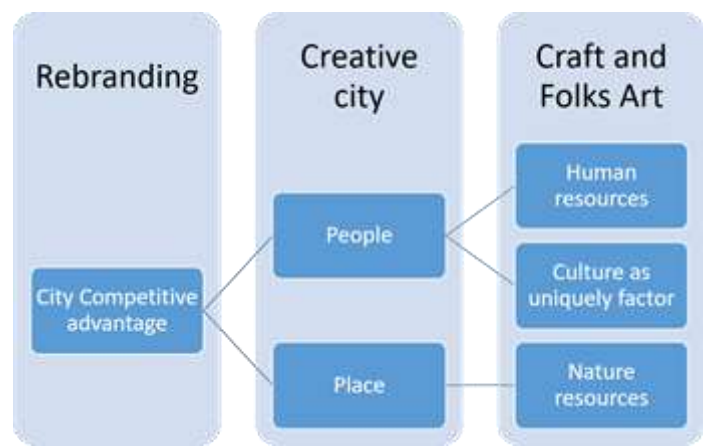

Figure 4. Formation of the concept of city competitiveness through $\mathrm{CCN}$ rebranding

Batik, which has been the Indonesian nation's property since 2009, is increasingly being confirmed through the city brand of Pekalongan is a city of creative craft in the form of Batik, which involves people and places. The religious people of Pekalongan can integrate into the development process of the port trading city in its history (Allo and Piliang 2015).

Figure 5 below describes the distribution of cultural heritage that currently exists in the city of Pekalongan. Cultural Heritage is a physical 
legacy currently registered by the Regional Government, for example, in the form of 5 (five) buildings that have a requirement of over 50 (fifty) years of age and do not at all involve the role of craft and craft-making humans which currently exist and are recognized internationally by UNESCO as a creative city of Batik.

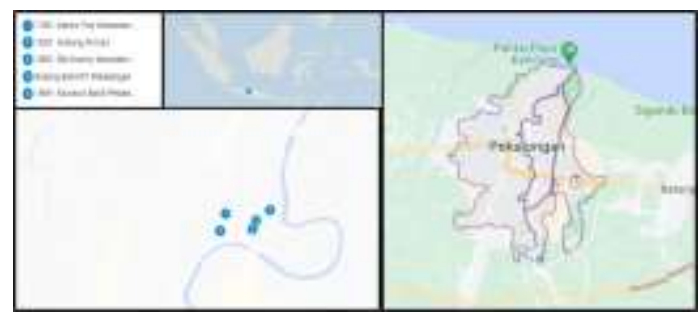

Figure 5. Map of the distribution of cultural heritage in Pekalongan City

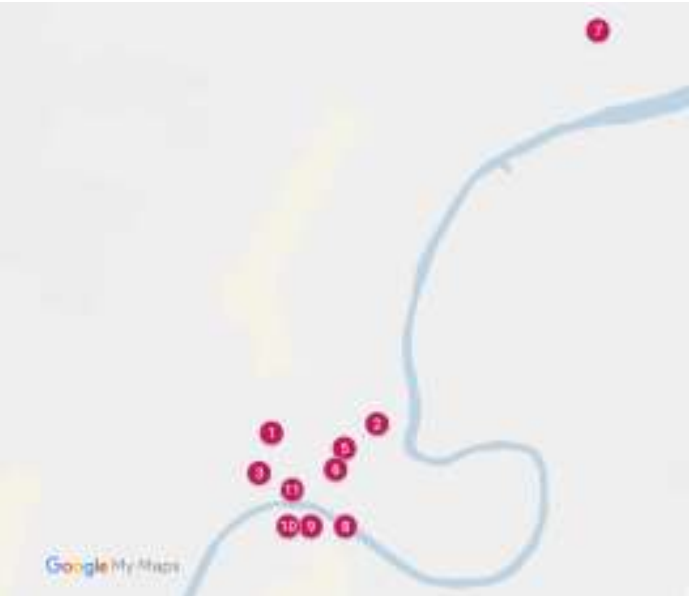

Figure 6. Communal attribute Pekalongan City

Figure 6 above depicts 11 (eleven) communal attributes or heritage obtained from significant data harvesting in social media, whose distribution in more detail can be seen in figure 7 below.

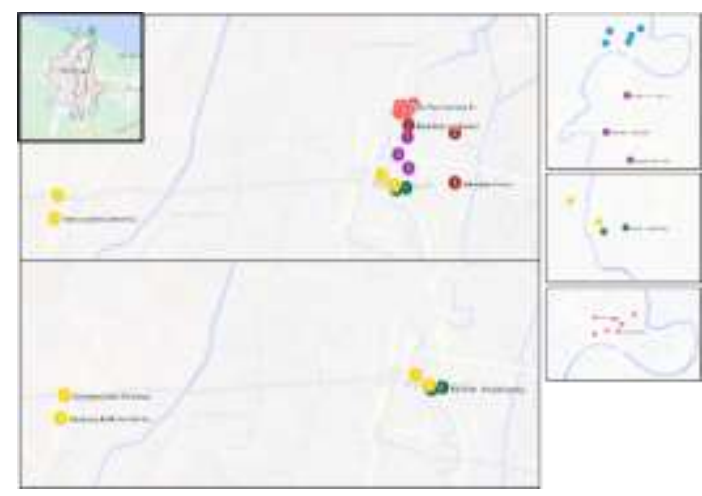

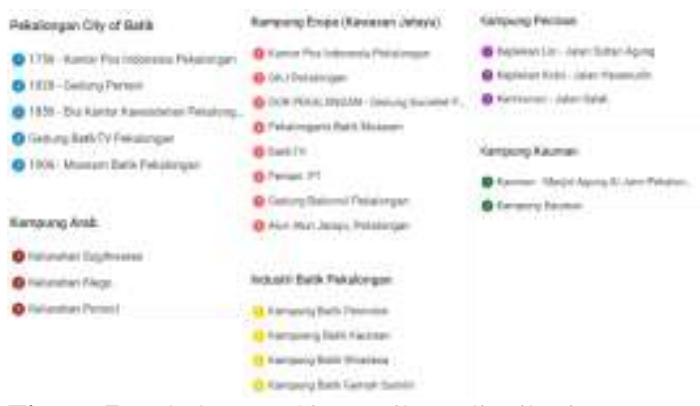

Figure 7. Pekalongan City attribute distribution map

Human and the local wisdom

The city of Pekalongan has now been recognized as the city of Batik. In contrast to the nearby Batik city of Surakarta and Yogyakarta, where Batik tradition was born from the art culture initially being centred from the palace, Pekalongan city has its uniqueness. Pekalongan city on the north coast of Central Java has a distinctive Batik motif that is a seven-form motif. The motif means the fusion of local culture with ethnic Chinese. Pekalongan is a city whose citizens consist of various ethnicities that live peacefully side by side (Allo and Piliang 2015).

In connection with the heritage that concerns the place and its uniqueness, the blend of cultures in Pekalongan is evidenced through worship places-built side by side, namely Al Ikhlas Mosque, St. Peter's Church and Po An Thian Temple, increasingly colouring diversity in Pekalongan. The various ethnic cultures that have lived together for an extended period since the founding of Pekalongan are depicted in figure 7 above.

Batik produced by the city of Pekalongan and having a different cultural meaning according to the people who have lived in it. Pekalongan Batik also has an advantage in the use of colour. Batik fabric can use eight colours to look more beautiful and attractive than Batiks from other regions. Pekalongan Batik has been integrated with the local community. Most of the production is done in the homes of residents.

In this way, the components of society and culture can make strides the competitiveness capability had by creating the make itsef, the nearby culture of the community that made it, as well as their endeavours to protect and create itself in arrange to be able to outlive concurring to the requirements of the improvement of the city within the future. 


\section{Conclusion}

Persistence of local wisdom, openness to diversity, and adaptive social organization are essential factors in the cultural heritage production process, continuity, and competitiveness.

The study on Batik heritage in the Pekalongan case has given us a better understanding of the local community's challenges and the city developing its competitive advantages.

The study has managed to find the relationship between the physical elements of city space and the strong meaning concerning the creative abilities possessed by its people, both tangible and intangible. It is this strength that underlies the distinctive and sustainable cultural development to build a city competitive advantage

A city is about people. A better place to live is related to the creativity of the people who are living within it. The relationship between people and place is reciprocal. A city with good socialeconomic and physical infrastructure will generate a better competition capacity through their cultural productions in tangible and intangible forms authentically.

Material and immaterial cultural products such as crafts and folk arts are the keys to a creative city's rebranding capacity. Batik, with all of its agents, systems, and processes, results from the quality of human resources, the uniqueness of the culture, and natural resources.

The study has demonstrated the combination of the Butterfly-Mamoli and Big Data gatherings analytical method's effectiveness in dissecting the relationship between people and place to extract the cultural "DNA" during the current COVID-19 pandemic limitations. Identifying the key factors, reciprocal relationships, and environmental prerequisites are the starting point for developing practical strategies and policies in the future.

This study also serves as an initial step towards a novel contribution in the city branding, place attachment, and the city competitive advantage theoretical discourses.

\section{Acknowledgement}

The author would like to express his gratitude to the Ministry of Research and High Technology of the Republic of Indonesia for the Post-Doctoral Grants given to conduct this research. The researcher also thanked the Pekalongan City Government, especially in Culture, Pekalongan City Tourism, Culture, Youth and Sports Office, Mrs Ninik Murniasih. We also thank the historical activist of Pekalongan Heritage Community, Bp. Mohammad Dirhamsyah, for all the assistance and information to complete this research.

\section{References}

Allo, Katherina, and Yasraf Amir Piliang. 2015. 'Historizing the City of Pekalongan'. Tawarikh 7 (1). https://doi.org/https://doi.org/10.2121/tawarik h.v7i1.626.

Bawole, Paulus. 2020. 'Pengembangan Kampung Kota Sebagai Salah Satu Alternatif Tujuan Wisata Minat Khusus'. ARTEKS: Jurnal Teknik Arsitektur 5 (1): 115-26. https://doi.org/10.30822/arteks.v5i1.362.

Blakely, Edward James, and Nancey Green Leigh. 2013. Planning Local Economic Development: Theory and Practice. 6th ed. Thousand Oaks, California, United States: SAGE Publications, Inc.

Campbell, Colin. 2005. 'The Craft Consumer'. Journal of Consumer Culture 5 (1): 23-42. https://doi.org/10.1177/1469540505049843.

Comunian, Roberta. 2011. 'Rethinking the Creative City'. Urban Studies 48 (6): 115779. https://doi.org/10.1177/0042098010370626.

Costa, Pedro. 2007. 'Creativity, Innovation and Territorial Agglomeration in Cultural Activities: The Roots of the Creative City'. In Creative Cities, Cultural Clusters and Local Economic Development, edited by Philip Cooke and Luciana Lazzeretti, 183-210. United Kingdom: Edward Elgar Publishing.

Costin, Cathy Lynne. 2001. 'Craft Production Systems'. In Archaeology at the Millennium, 273-327. Boston, MA: Springer US. https://doi.org/10.1007/978-0-387-726113_8.

- 2015. 'Craft Specialization'. In The International Encyclopedia of Human Sexuality. United States: John Wiley \& Sons, Ltd.

Dormer, Peter. 1997. The Culture of Craft (Studies in Design and Material Culture). 
Manchester, England: Manchester University Press.

Florek, Magdalena. 2011. 'No Place like Home: Perspectives on Place Attachment and Impacts on City Management'. Journal of Town \& City Management 1 (4): 346-54.

Florida, Richard. 2004. Cities and the Creative Class. 1st ed. United Kingdom: Taylor \& Francis: Psychology Press.

Fuller, Glen, Caroline Hamilton, and Kirsten Seale. 2013. 'Working with Amateur Labour: Between Culture and Economy'. Cultural Studies $\quad$ Review $19 \quad 1$ (1). https://doi.org/10.5130/csr.v19i1.3223.

Huhtamaa, Inkeri. 2010. Namibian Bodily Appearance and Handmade Objects: The Meanings of Appearance Culture and Handmade Objects from the Perspective of the Craft Persons. Finland: Aalto University.

Ingold, Tim. 2016. Redrawing Anthropology Materials, Movements, Lines. Farnham, United Kingdom: Routledge: Ashgate Publishing, Ltd.

Landry, Charles. 2005. 'Lineages of the Creative City'. Creativity and the City, Netherlands Architecture Institute. Netherlands.

. 2008. The Creative City: A Toolkit for Urban Innovators. 2nd ed. United Kingdom: Routledge.

Markusen, Ann. 2006. 'Cultural Planning and the Creative City'. In Annual American Collegiate Schools of Planning Meetings, Ft. Worth, TX. Citeseer, 2:12-24. Washington, United States: Regional and Industrial Economics Humphrey Institute of Public Affairs University of Minnesota. http://citeseerx.ist.psu.edu/viewdoc/download ?doi=10.1.1.460.8123\&rep=rep1\&type=pdf.

Mills, Kathy A. 2018. 'What Are the Threats and Potentials of Big Data for Qualitative Research?' Qualitative Research 18 (6): 591603. https://doi.org/10.1177/1468794117743465.

Nursanty, Eko. 2021. 'The Anatomy of Place Branding: Relating Place Transformation to Community Identity'. Place Branding and Public Diplomacy 17 (1): 19-35. https://doi.org/10.1057/s41254-019-00157-z.

Oaks, Thousand, Trudie Aberdeen, and Educational Psychology. 2013. 'Yin, R. K. (2009). Case Study Research: Design and Methods (4th Ed.). Thousand Oaks, CA: Sage.' The Canadian Journal of Action
Research $14 \quad$ (1): $69-71$. https://doi.org/10.33524/cjar.v14i1.73.

Sasaki, Masayuki. 2010. 'Urban Regeneration through Cultural Creativity and Social Inclusion: Rethinking Creative City Theory through a Japanese Case Study'. Cities 27 (June): S3-9. https://doi.org/10.1016/j.cities.2010.03.002.

- 2011. 'Urban Regeneration through Cultural Diversity and Social Inclusion'. Journal of Urban Culture Research 2: 30-49. https://so04.tcithaijo.org/index.php/JUCR/article/view/2038 7.

Scott, Allen John. 2014. 'Beyond the Creative City: Cognitive-Cultural Capitalism and the New Urbanism'. Regional Studies 48 (4): 565-78.

https://doi.org/10.1080/00343404.2014.8910 10.

The Japan Foundation, and JENESYS East Asia Future Leaders Programme. 2009. Urban Community Development Inspired by Culture : The Potential of Creative Cities, July 29-August 7, 2008. Japan: The Japan Foundation. https://www.jpf.go.jp/e/project/intel/archive/j enesys/pdf/report_b.pdf.

Varbanova, Lidia. 2007. 'Our Creative Cities Online'. In The Creative City: Crossing Visions and New Realities in the Region, edited by N. Svob-Dokic, 9-18. Zagreb: Institute of International Relations.

Yencken, David. 1988. The Creative City. Meanjin. Melbourne: Meanjin. https://doi.org/10.5040/9781849666565.ch005.

Yin, Robert K. 2008. Case Study Research: Design and Methods (Applied Social Research Methods). 4th ed. Thousand Oaks, California: SAGE Publications, Inc.

\section{Author(s) contribution}

Eko Nursanty contributed to the research concepts preparation, methodologies, investigations, data analysis, visualization, articles drafting and revisions.

Indah Susilowati contribute to the research concepts preparation and literature reviews, data analysis, of article drafts preparation and validation. 